\title{
Breve Análise das Opiniões Consultivas da Corte Interamericana de Direitos Humanos no Âmbito da Migração
}

\begin{abstract}
Oscar Silvestre Filho
Doutorado em Direito pela Pontifícia Universidade Católica de São Paulo (PUC/SP). Mestrado em Direito pela Universidade Nove de Julho (Uninove/SP). Especialização em Direito Civil e Processual Civil pela Escola Paulista de Direito (EPD/SP). Graduação em Direito pela Pontifícia Universidade Católica de Campinas (PUC/Campinas). Advogado. Professor-assistente de Direitos Humanos da Pontifícia Universidade Católica de São Paulo (PUC/SP). Ex-Pesquisador Capes. Membro associado do Conselho Nacional de Pesquisa e Pós-Graduação em Direito (Conpedi). http://lattes.cnpq.br/0232575809711404. http://orcid.org/0000-0002-1825-0097. oscarsilvestre2005@hotmail.com
\end{abstract}

\section{Eduardo Dias de Souza Ferreira}

Graduação em Direito pela Pontifícia Universidade Católica de São Paulo (1987). Mestrado (2001) e Doutorado em Direito (2006) pela mesma Instituição. Professor da Pontifícia Universidade Católica de São Paulo na Graduação e na Pós-Graduação na área de Direitos Humanos com ênfase em Infância e Juventude. Chefe do Departamento de Direitos Difusos e Coletivos. Integra o corpo docente dos cursos de Especialização da Escola Superior do Ministério Público de São Paulo. 42o Procurador de Justiça Cível no MPSP e ex-promotor da Justiça de Infância e Juventude da capital, com atribuições na área de Direitos Difusos e Coletivos da Infância. Membro do Grupo Pediatria Legal da Sociedade de Pediatria de São Paulo/SP. http://lattes.cnpq.br/8497057300721560. http://orcid.org/0000-0002-7543-2567.edudiasf@terra.com.br

O objetivo deste artigo teve a finalidade de estudar os Pareceres Consultivos OC - 18/03 e OC -21/14, ambos emitidos pela Corte Interamericana de Direitos Humanos, relativamente à condição jurídica dos migrantes e necessidade de proteção no âmbito internacional. A finalidade foi a de analisar os direitos e garantias ressaltadas pela Corte Interamericana no âmbito da migração, atentando-se para a situação de vulnerabilidade dos migrantes e a perspectiva dos direitos humanos no plano global. Por fim, concluiu-se que aludidos Pareceres estabelecem novas diretrizes no tratamento jurídico a ser conferido aos migrantes, tendo em vista o grande enfoque nos direitos humanos consagrados no âmbito nacional e internacional.

Palavras-chave: Pareceres consultivos. Corte Interamericana. Direitos humanos. Migração.

\section{BRIEF ANALYSIS OF THE ADVISORY OPINIONS OF THE INTER-AMERICAN} COURT OF HUMAN RIGHTS IN THE FRAMEWORK OF MIGRATION

\section{ABSTRACT}

The objective of this article was to study Advisory Opinions OC-18/03 and OC-21/14, both issued by the Inter-American Court of Human Rights, regarding the legal status of migrants and the need for protection at the international level. The purpose was to analyze the rights and guarantees highlighted by the Inter-American Court in the context of migration, taking into account the situation of vulnerability of migrants and the perspective of human rights at the global level. Finally, it was concluded that the aforementioned Opinions establish new guidelines on the legal treatment to be given to migrants, in view of the great focus on human rights enshrined at the national and international levels.

Keywords: Advisory opinions. Inter-American Court. Human rights. Migration.

SUMÁRIO

1 Introdução. 2 Análise do parecer consultivo OC-18/03 de 17 de setembro de 2003, solicitado pelos Estados Unidos Mexicanos - a condição jurídica e os direitos dos migrantes indocumentados. 3 Análise do parecer consultivo OC 21 de 19 agosto de 2014 sobre direitos e garantias de crianças no contexto da migração e/ou em necessidade de proteção internacional. 3.1 Da migração. 3.2 Das garantias do devido processo no âmbito migratório. 3.3 Do princípio da não privação de liberdade de crianças e do princípio de não devolução (Non-Refoulement). 4 Conclusão. 5 Referências. 


\section{Humanos e \\ Democracia}

\section{INTRODUÇÃO}

O fenômeno migratório manifesta hoje um dos aspectos mais relevantes da modernidade. Pessoas migram de Federação para Federação, de Estados para Estados ou até mesmo entre municípios.

Aludido fenômeno tem despertado interesse nos pesquisadores, pois quando se trata de migração, especialmente no contexto internacional, nota-se invariavelmente as desproporcionalidades econômicas existentes entre as nações espalhadas pelo mundo.

Países subdesenvolvidos apresentam sérios problemas sociais, o que, na maioria das vezes, ocasiona o êxodo dos seus habitantes. Nesse aspecto, cumpre assinalar que indicadores importantes desses acontecimentos migratórios estão relacionados a questões políticas e sociais, razão pela qual buscam os migrantes melhores oportunidades de vida e o direito a ter direitos.

Assim, expõe-se a análise dos Pareceres Consultivos OC-18/03 e OC-19/14, ambicionando discorrer o pleito de direitos no âmbito da migração, especialmente no tocante às políticas adotadas no processo migratório e o respeito dos direitos fundamentais aos indivíduos.

\section{ANÁLISE DO PARECER CONSULTIVO OC-18/03 DE 17 DE SETEMBRO DE 2003, SOLICITADO PELOS ESTADOS UNIDOS MEXICANOS - A CONDIÇÃO JURÍDICA E OS DIREITOS DOS MIGRANTES INDOCUMENTADOS}

Em 10 de maio de 2002 os Estados Unidos Mexicanos solicitaram, com fundamento no artigo 64.1 da Convenção Americana sobre Direitos Humanos (doravante denominada "a Convenção Americana", "a Convenção" ou "o Pacto de San José"), à Corte Interamericana de Direitos Humanos um pedido de Parecer Consultivo relativamente à privação dos direitos trabalhistas dos migrantes e sua compatibilidade com a obrigação dos Estados americanos de garantir os princípios de igualdade jurídica, não discriminação e proteção igualitária previstos em instrumentos internacionais de proteção aos direitos humanos, ressaltando a subordinação ou condicionamento da observância das obrigações impostas pelo Direito Internacional dos Direitos Humanos, conforme razões expostas pelo Estado Mexicano:

"Os trabalhadores migrantes, bem como o restante das pessoas, devem ter garantido o desfrute e exercício dos direitos humanos nos Estados onde residem. Entretanto, sua vulnerabilidade os torna alvo fácil de violações a seus direitos humanos, em especial baseadas em critérios de discriminação e, em consequência, coloca-os em uma situação de desigualdade perante a lei quanto [a]o desfrute e exercício efetivos destes direitos.

[...]

No contexto já descrito, preocupa-Ihe profundamente o governo do México a incompatibilidade de interpretações, práticas e expedição de leis por parte de alguns Estados da região, com o sistema de direitos humanos da OEA. O governo do México considera que tais interpretações, práticas ou leis implicam negar, entre outros, direitos trabalhistas com base em critérios discriminatórios fundamentados na condição migratória dos trabalhadores indocumentados. $O$ anterior poderia alentar os empregadores a utilizar essas leis ou interpretações para justificar a perda progressiva de outros direitos trabalhistas. Por exemplo: pagamento de horas extras, antiguidade no emprego, salários atrasados, licença-maternidade, abusando assim da condição de vulnerabilidade em que se encontram 
os trabalhadores migrantes indocumentados. Nesse contexto, as violações aos instrumentos internacionais que protegem os direitos humanos dos trabalhadores migrantes na região constituem uma ameaça real para a vigência dos direitos protegidos por tais instrumentos". ${ }^{1}$

Nesse sentido, o Parecer OC-18/03 teve por finalidade o reconhecimento pela comunidade internacional da necessidade de proteção especial dos direitos humanos dos migrantes em situação de vulnerabilidade, tendo em vista que países da região negam a aplicação dos direitos humanos e trabalhistas, com fundamento em critérios discriminatórios por se tratar de trabalhadores indocumentados.

A Corte Interamericana dos Direitos Humanos, no entanto, expressou manifestação no sentido de que os países devem assegurar o respeito aos direitos humanos, bem como o princípio da não discriminação, constituindo imperativo constitucional aplicável a todas as nações, independentemente de serem partes ou não de tratados internacionais, conforme se verifica no parecer OC-18/03:

A Corte, nesta oportunidade, precisou o alcance das obrigações dos Estados membros da Organização dos Estados Americanos, de respeitar e garantir os direitos trabalhistas dos trabalhadores migrantes indocumentados, independentemente de sua nacionalidade, ao estabelecer que o princípio de igualdade e não discriminação, que é fundamental para a proteção destes direitos, pertence ao jus cogens. ${ }^{2}$

Esta precisão conduz a Corte a declarar, igualmente, que os Estados, sejam ou não partes de um determinado tratado internacional, estão obrigados a proteger os direitos de igualdade e não discriminação e que essa obrigação tem efeitos erga omnes, não apenas em relação aos Estados, mas também frente a terceiros e particulares. Os Estados devem, portanto, respeitar e garantir os direitos trabalhistas dos trabalhadores, seja qual for seu status migratório, e, ao mesmo tempo, devem impedir que empregadores privados violem os direitos dos trabalhadores migrantes indocumentados ou que a relação de trabalho viole os padrões mínimos internacionais. Para que seja efetiva a tutela dos direitos trabalhistas dos imigrantes indocumentados é necessário que se garanta a estes o acesso à justiça e o devido processo legal. ${ }^{3}$

\footnotetext{
Trecho extraído do Parecer Consultivo OC-18/03 de 17 de setembro de 2003, solicitado pelos Estados Unidos Mexicanos A Condição Jurídica e os Direitos Dos Migrantes Indocumentados.

2 Afirmar que o princípio de igualdade e não discriminação pertence ao domínio do jus cogens, tem, segundo o Tribunal Europeu de Direitos Humanos, vários efeitos jurídicos: o reconhecimento de que a norma é hierarquicamente superior a respeito de qualquer norma de Direito Internacional, excetuando outras normas de jus cogens; em caso de conflito, teria primazia a norma de jus cogens frente a qualquer outra regra de Direito Internacional, e seria nula ou careceria de efeitos jurídicos a disposição que contradiga a norma imperativa. (Tomado dos argumentos das Clínicas Jurídicas da Faculdade de Direito da Universidade San Francisco de Quito).

3 No Parecer Consultivo OC-16/99 de 10 de outubro de 1999, a Corte Interamericana de Direitos Humanos afirmou que "para que exista 'devido processo legal' é preciso que um acusado possa exercer seus direitos e defender seus interesses de forma efetiva e em condições de igualdade processual com outros acusados. Com efeito, é útil recordar que o processo é um meio para assegurar, na maior medida possível, a solução justa de uma controvérsia. A esse fim responde o conjunto de atos de diversas características geralmente reunidos sob o conceito do devido processo legal. 0 desenvolvimento histórico do processo, coerente com a proteção do indivíduo e a realização da justiça, trouxe consigo a incorporação de novos direitos processuais. São exemplos deste caráter evolutivo do processo os direitos a não se autoincriminar e a depor na presença de um advogado, que hoje em dia figuram na legislação e na jurisprudência dos sistemas jurídicos mais avançados. Desta forma, progressivamente, foi estabelecido o aparato das garantias judiciais recopiladas pelo artigo 14 do Pacto Internacional sobre Direitos Civis e Políticos, que podem e devem agregar-se, sob o mesmo conceito, de outras garantias apresentadas por diversos instrumentos do Direito Internacional".
} 


\section{Democracia}

Assegurou-se também a todos os estrangeiros em situação irregular a ampla defesa e o devido processo legal, uma vez que o migrante tem o direito de se defender, mediante processo, nos casos que envolvam violações aos direitos humanos, expulsão, deportação ou até mesmo a detenção do migrante nos respectivos Estados.

Sobre o assunto, expressa o Parecer:

"A proclamação de direitos sem a provisão de garantias para exercê-los fica no vazio. Converte-se em uma formulação estéril, que semeia expectativas e produz frustrações. Por isso é preciso estabelecer as garantias que permitam reivindicar o reconhecimento dos direitos, recuperá-los quando foram desconhecidos, restabelecê-los se foram violados e colocá-los em prática quando seu exercício tropeça em obstáculos indevidos. A isso atende o princípio de acesso igual e expresso à proteção jurisdicional efetiva, isto é, a possibilidade real de ter acesso à justiça através dos meios que o ordenamento interno proporciona a todas as pessoas, com a finalidade de alcançar uma solução justa à controvérsia que se suscitou. Em outros termos: acesso formal e material à justiça.

A esse acesso serve o devido processo, amplamente examinado pela Corte Interamericana de Direitos Humanos no exercício de suas competências consultiva e contenciosa. A rigor, o devido processo é o meio consequente com o mais avançado conceito dos direitos humanos para assegurar a efetiva realização destes direitos: um método ou fator para a eficácia do direito em seu conjunto e dos direitos subjetivos em casos concretos. O devido processo, conceito dinâmico guiado e desenvolvido sob um modelo garantidor que serve aos interesses e direitos individuais e sociais, bem como ao supremo interesse da Justiça, constitui um princípio orientador para a devida solução dos litígios e um direito primordial de todas as pessoas. Aplica-se à solução de controvérsias de qualquer natureza - entre elas, obviamente, as trabalhistas - e às petições e reivindicações que se apresentam perante quaisquer autoridades: judiciais ou administrativas.

O devido processo, em seus elementos que interessam para o objeto do OC-18/2003, implica, por uma parte, a maior igualdade - equilíbrio, "igualdade de armas" - entre os litigantes, particularmente importante quando em um extremo da disputa se encontra o vulnerável trabalhador migrante e no outro o empregador dotado de direitos suficientes e eficientes, uma igualdade que apenas se consegue - na maioria dos casos, que refletem a verdadeira dimensão do problema coletivo - quando o poder público incorpora, através de leis e critérios de interpretação e aplicação, os elementos de compensação ou correção aos que antes me referi; e, além disso, o cumprimento claro e fluído do dever que tem o Estado de oferecer o serviço de justiça, sem distinção e, muito menos, discriminação, que implicaria, de entrada, a derrota do acusado débil”. ${ }^{4}$

A Corte ainda menciona que não é considerada discriminatória a distinção entre migrantes regulares e irregulares, desde que tal distinção seja feita de forma razoável e proporcional, sem qualquer violação aos direitos humanos, tendo em vista que a regularização no país não poderá ser utilizada como critério para aplicação dos princípios da igualdade e da não discriminação.

\footnotetext{
4 Trecho extraído do Parecer Consultivo OC-18/03 de 17 de setembro de 2003, solicitado pelos Estados Unidos Mexicanos A Condição Jurídica e os Direitos Dos Migrantes Indocumentados.
} 
No que diz respeito aos trabalhadores migrantes, a Corte ressaltou que a criação de vínculos de emprego em determinado trabalho acarreta a aquisição dos direitos trabalhistas previstos na legislação do respectivo Estado, pois o respeito e garantia dos direitos trabalhistas devem ser aplicados de forma igualitária, sem qualquer espécie de discriminação, independentemente da nacionalidade do migrante.

"Os direitos trabalhistas surgem necessariamente da condição de trabalhador, entendida em seu sentido mais amplo. Toda pessoa que irá realizar, realize ou tenha realizado uma atividade remunerada, adquire imediatamente a condição de trabalhador e, consequentemente, os direitos inerentes a esta condição. $O$ direito do trabalho, seja regulamentado no âmbito nacional ou internacional, é um ordenamento tutelar dos trabalhadores, isto é, regulamenta os direitos e obrigações do empregado e do empregador, independentemente de qualquer outra consideração de caráter econômico ou social. Uma pessoa que ingressa em um Estado e estabelece relações trabalhistas, adquire seus direitos humanos trabalhistas nesse Estado de emprego, independentemente de sua situação migratória, visto que o respeito e garantia do desfrute e exercício destes direitos devem se realizar sem nenhuma discriminação". ${ }^{5}$

Consequentemente, o Estado tem a obrigação de respeitar e garantir os direitos humanos trabalhistas, sem qualquer espécie de discriminação nas relações de trabalho, respeitado, ainda, os padrões mínimos estabelecidos no âmbito internacional.

Acerca do assunto, explicita-se:

"Que o Estado tem a obrigação de respeitar e garantir os direitos humanos trabalhistas de todos os trabalhadores, independentemente de sua condição de nacionais ou estrangeiros, e não tolerar situações de discriminação em detrimento destes nas relações de trabalho que se estabeleçam entre particulares (empregador-trabalhador). O Estado não deve permitir que os empregadores privados violem os direitos dos trabalhadores, nem que a relação contratual viole os padrões mínimos internacionais.

Que os trabalhadores, ao serem titulares dos direitos trabalhistas, devem contar com todos os meios adequados para exercê-los. Os trabalhadores migrantes indocumentados possuem os mesmos direitos trabalhistas que correspondem aos demais trabalhadores do Estado receptor, e este último deve tomar todas as medidas necessárias para que assim se reconheça e se cumpra na prática". ${ }^{6}$

Esclareceu ainda que os Estados e os particulares não estão obrigados a estabelecerem vínculo de emprego com trabalhadores irregulares, mas caso estabeleçam, ficam obrigados a garantirem os mesmos direitos trabalhistas previstos para os trabalhadores regulares no país, na medida em que há obrigação pela nação na aplicação dos direitos empregatícios tanto no campo do Direito Público quanto no Direito Privado, caracterizando, assim, certa responsabilidade internacional por parte do Estado.

Nesse sentido:

\footnotetext{
Trecho extraído do Parecer Consultivo OC-18/03 de 17 de setembro de 2003, solicitado pelos Estados Unidos Mexicanos A Condição Jurídica e os Direitos Dos Migrantes Indocumentados.

6 Trecho extraído do Parecer Consultivo OC-18/03 de 17 de setembro de 2003, solicitado pelos Estados Unidos Mexicanos A Condição Jurídica e os Direitos Dos Migrantes Indocumentados.
} 


\title{
Humanos e
}

Democracia

\begin{abstract}
"Que os Estados têm a obrigação geral de respeitar e garantir os direitos fundamentais. Com este propósito, devem adotar medidas positivas, evitar tomar iniciativas que limitem ou violem um direito fundamental, e eliminar as medidas e práticas que restrinjam ou violem um direito fundamental.

Que o descumprimento pelo Estado, através de qualquer tratamento discriminatório, da obrigação geral de respeitar e garantir os direitos humanos, gera sua responsabilidade internacional". ${ }^{7}$
\end{abstract}

Essa responsabilidade internacional, no caso da violação dos direitos humanos, caracteriza-se de diversas formas: a primeira delas decorre do Estado como empregador; a segunda praticada por um particular diante da ausência do Estado na fiscalização entre particulares; a terceira quando o migrante, empregado pelo setor público ou privado, seja privado de direitos trabalhistas previstos pelo Estado, a exemplo de aposentadoria, e quarto e último quando o empregado, no pleito de seus direitos, for privado da ampla defesa e de processo judicial.

Com isso, diante da vulnerabilidade dos migrantes em situação irregular, foram previstas várias hipóteses no sentido de assegurar a proteção dos trabalhadores indocumentados em solo estrangeiro, pois, em virtude das dificuldades de se encontrar um emprego condizente, uma vez que determinada situação propicia o pagamento de salários baixíssimos e condições precárias de trabalho, faz com que muitas empresas submetam esses migrantes a trabalhos análogos à condição de escravos. A esse respeito constantemente tem-se notado na mídia, principalmente na cidade de São Paulo, a situação dos bolivianos que trabalham em condições sub-humanas em troca de $\mathrm{R} \$ \mathbf{0 , 2 0}$ (vinte centavos) por peça de roupa confeccionada, de acordo com o pronunciamento da Corte:

\begin{abstract}
"Neste Parecer, a Corte se pronunciou sobre os direitos que devem ser reconhecidos e aplicados pelos Estados aos trabalhadores que, por distintas circunstâncias, emigram de seus países em procura de bem-estar econômico, e que ao não terem status migratório legal, podem ser vítimas de violações de seus direitos, entre outros, de seus direitos trabalhistas, de seus direitos à integridade, à igualdade e não discriminação. Nesse sentido, o Estado solicitante do Parecer da Corte refere-se ao fato concreto de que, quase seis milhões de trabalhadores mexicanos vivem fora do território nacional, dos quais aproximadamente dois milhões e meio são trabalhadores migrantes indocumentados. Acrescenta que 'apenas em cinco meses, (do ano de 2002), o México teve que intervir, através de suas representações consulares, em aproximadamente 383 casos em defesa dos trabalhadores mexicanos, por discriminação trabalhista, salários não pagos, indenizações por doenças adquiridas nos centros de trabalho e acidentes de trabalho, entre outros motivos'"'.
\end{abstract}

Assim, a Corte listou, por exemplo, a proibição do trabalho forçado ou obrigatório, proibição do trabalho infantil, proteção ao trabalho feminino, com a garantia dos mesmos direitos previstos ao trabalhador masculino, como a associação sindical, duração de jornada razoável, descanso e indenização.

\footnotetext{
Trecho extraído do Parecer Consultivo OC-18/03 de 17 de Setembro de 2003, solicitado pelos Estados Unidos Mexicanos A Condição Jurídica e os Direitos Dos Migrantes Indocumentados.

8 Trecho extraído do Parecer Consultivo OC-18/03 de 17 de Setembro de 2003, solicitado pelos Estados Unidos Mexicanos A Condição Jurídica e os Direitos Dos Migrantes Indocumentados.
} 
Com isso, constata-se que o objetivo central desse documento é demonstrar que os deslocamentos migratórios são protegidos pelo Direito Internacional dos Direitos Humanos, observando-se que todos os trabalhadores migrantes, inclusive os indocumentados, devem ter asseguradas a proteção dos direitos humanos, a igualdade e a não discriminação:

"A ideia básica de todo o documento é no sentido de que os deslocados internos não perdem os direitos que lhes são inerentes como seres humanos em razão do deslocamento, e estão protegidos pela normativa do Direito Internacional dos Direitos Humanos e do Direito Internacional Humanitário. ${ }^{9}$ Na mesma linha de raciocínio, a ideia básica subjacente à Convenção Internacional sobre a Proteção dos Direitos de Todos os Trabalhadores Migrantes e dos Membros das suas Famílias (1990) é no sentido de que todos os trabalhadores qualificados como migrantes de acordo com suas disposições, devem desfrutar seus direitos humanos, independentemente de sua situação jurídica; daí a posição central ocupada, também neste contexto, pelo princípio da não discriminação. ${ }^{10} \mathrm{Em}$ resumo, os trabalhadores migrantes, inclusive os indocumentados, são titulares dos direitos humanos fundamentais, que não se condicionam por sua situação jurídica (irregular ou não). ${ }^{11} \mathrm{Em}$ conclusão sobre este ponto, ao princípio fundamental da igualdade e não discriminação está reservada, desde a Declaração Universal de 1948, um posicionamento verdadeiramente central no âmbito do Direito Internacional dos Direitos Humanos". ${ }^{12}$

Do exposto, passa-se agora para a análise do Parecer Consultivo OC-21/14, relativamente à migração de crianças na América Latina.

\section{ANÁLISE DO PARECER CONSULTIVO OC 21 DE 19 AGOSTO DE 2014 SOBRE DIREITOS E GARANTIAS DE CRIANÇAS NO CONTEXTO DA MIGRAÇÃO E/OU EM NECESSIDADE DE PROTEÇÃO INTERNACIONAL}

Em 19 agosto de 2014 as Repúblicas Federativas da Argentina, Brasil, Paraguai e Uruguai, os denominados "Estados Solicitantes", apresentaram perante a Corte Interamericana de Direitos Humanos Opinião Consultiva (OC) sobre a infância migrante na América Latina.

Referido documento teve por objetivo solicitar à Corte internacional a definição das obrigações dos Estados quanto aos padrões jurídicos a serem utilizados nas políticas migratórias, tendo em vista que a situação deveria ser interpretada de acordo com a Convenção Americana dos Direitos Humanos, com a Declaração Americana dos Direitos e Deveres do Homem e com a Convenção Interamericana para Prevenir e Punir a Tortura.

\footnotetext{
9 R. Cohen e F. Deng, Masses in Flight: The Global Crisis of Internal Displacement, Washington D.C., Brookings Institution, 1998, p. 74.

10 Tal como enunciado em seu artigo 7ㅇ.

${ }^{11}$ A. A. Cançado Trindade, Elementos para un Enfoque de Derechos Humanos del Fenómeno de los Flujos Migratorios Forzados, Cidade da Guatemala, OIM/IIDH (Cadernos de Trabalho sobre Migração n 5), 2001, p. 13,18.

12 Trecho extraído do Parecer Consultivo OC-18/03 de 17 de setembro de 2003, solicitado pelos Estados Unidos Mexicanos A Condição Jurídica e os Direitos Dos Migrantes Indocumentados.
} 
Os aludidos Estados manifestaram as suas considerações sobre a questão da migração, dando, assim, origem ao parecer OC-21 de $2014,{ }^{13}$ ora objeto em análise.

\subsection{Da migração}

A migração é um fenômeno internacional que pode envolver dois ou mais Estados. $\mathrm{O}$ fluxo migratório, especificamente no que diz respeito ao tema, acarreta o deslocamento de pessoas por diversas razões:

Em busca de oportunidades, seja por razões econômicas ou educacionais; com fins de reunificação familiar, a fim de reagrupar-se com familiares que já migraram; por mudanças repentinas ou progressivas do meio ambiente que afetam adversamente sua vida ou suas condições de vida; por danos derivados do crime organizado, desastres naturais, abuso familiar ou extrema pobreza; para serem transportados no contexto de uma situação de exploração, incluindo o tráfico infantil; para fugir de seu país, seja por temor fundado de ser perseguido por determinados motivos ou porque sua vida, segurança ou liberdade foram ameaçadas pela violência generalizada, agressão estrangeira, conflitos internos, violação massiva dos direitos humanos ou outras circunstâncias que tenham perturbado gravemente a ordem pública. Apesar de as crianças geralmente se trasladarem com seus pais, membros da família ampliada ou outros adultos, atualmente um número crescente e significativo migra de forma independente e sem companhia. ${ }^{14}$

\footnotetext{
${ }^{13} \mathrm{Na}$ América Latina e no Caribe considera-se que aproximadamente 25 milhões de pessoas migraram para países da América do Norte e Europa, enquanto [...] outros 6 milhões migraram a outros países dentro da região. Delas, uma quantidade crescente, ainda incalculável, são meninos, meninas e adolescentes, alguns dos quais migram junto a seus pais (ou com um deles) ao tempo que outros o fazem de maneira crescente, em forma não acompanhada ou separada. [...]

[... Os meninos e meninas [...] emigram por motivos diversos, seja por reagrupação familiar, procura de melhores condições econômicas, sociais ou culturais, para fugir da pobreza extrema, da degradação ambiental, da violência ou de outras formas de abuso e perseguição a que se vêm submetidos. [...]

[... As pessoas migrantes em situação migratória irregular, por um lado, e os meninos e meninas, pelo outro, são grupos sociais que se encontram em uma condição de vulnerabilidade. Ambos [os] coletivos requerem, por isso, um compromisso especial por parte dos Estados que devem procurar o respeito, a proteção e a garantia de seus direitos fundamentais [tendo em conta] um enfoque transversal de idade que tenha devidamente em consideração os direitos dos meninos e meninas afetados pela migração. [...]

$\mathrm{Na}$ atualidade, a utilização da privação de liberdade de migrantes (adultos e meninos) associada à infração das normas migratórias constitui uma problemática que suscita uma profunda preocupação em diferentes âmbitos nacionais e internacionais. [...]

Estabelecido o princípio de não criminalização, ainda restam muitas questões pendentes em relação [ao] reconhecimento dos direitos humanos dos migrantes e, em particular, sobre o reconhecimento e a proteção dos direitos humanos das crianças migrantes. [...]

Neste cenário, resulta fundamental que a [...] Corte Interamericana de Direitos Humanos defina com maior precisão quais são os padrões, princípios e obrigações concretas que os Estados devem cumprir em matéria de direitos humanos das pessoas migrantes, em particular no que diz respeito aos direitos dos meninos e meninas migrantes e filhos/as de migrantes [...] nos seguintes temas: 1. Procedimentos para a determinação de necessidades de proteção internacional e de medidas de proteção especial dos meninos, meninas e adolescentes migrantes; 2 . Sistema de garantias que se deveria aplicar nos procedimentos migratórios que envolvam meninos, meninas e adolescentes migrantes; 3 . Padrões para a aplicação de medidas cautelares em um procedimento migratório sobre a base do princípio de não detenção de meninas e meninos migrantes; 4 . Medidas de proteção de direitos que deveriam dispor-se de maneira prioritária e que não implicam restrições à liberdade pessoal; 5. Obrigações estatais em casos de custódia de meninos e meninas por motivos migratórios; 6. Garantias do devido processo perante medidas que impliquem [na] privação da liberdade de meninos e meninas no âmbito de procedimentos migratórios; 7. Princípio de não devolução em relação a meninas e meninos migrantes; 8. Procedimentos para a identificação e tratamento de meninos e meninas eventuais solicitantes de asilo ou refúgio; 9 . 0 direito à vida familiar dos meninos e meninas em casos de se dispor a expulsão por motivos migratórios de seus pais.

${ }^{14}$ Relatório do Relator Especial sobre os Direitos Humanos dos Migrantes, Jorge Bustamante, Promoção e Proteção de todos os Direitos Humanos, Civis, Políticos, Econômicos, Sociais e Culturais, incluindo o Direito ao Desenvolvimento, UN Doc. A/ HRC/11/7, 14 de maio de 2009, par. 19.
} 
Embora a migração ocorra por diversos fenômenos, o que também foi objeto da pauta dessa consulta é a proteção internacional oferecida por um Estado a uma pessoa estrangeira, ainda que seus direitos humanos estejam violados ou ameaçados no seu país de origem, tendo em vista que a proteção internacional dos direitos humanos deve abarcar

(a) a proteção recebida pelas pessoas solicitantes de asilo e refugiadas com fundamento nos convênios internacionais ou nas legislações internas; (b) a proteção recebida pelas pessoas solicitantes de asilo e refugiadas com fundamento na definição ampliada da Declaração de Cartagena; (c) a proteção recebida por qualquer estrangeiro com base nas obrigações internacionais de direitos humanos e, em particular, o princípio de não devolução e a denominada proteção complementar ou outras formas de proteção humanitária, e (d) a proteção recebida pelas pessoas apátridas de acordo com os instrumentos internacionais sobre a matéria. ${ }^{15}$

Nota-se, entretanto, que há direito de se reivindicar e de receber asilo como um direito individual, bem como de receber proteção internacional em território estrangeiro. Além disso, o comitê dos direitos da criança também ressaltou que a interpretação de aludidos direitos merece ser analisada nos aspectos idade e gênero, levando-se em conta todos os fatores que levaram ao deslocamento territorial dessas pessoas.

Avalia a Corte que as autoridades fronteiriças não podem barrar a entrada de crianças estrangeiras no território nacional, ainda que desacompanhadas, e nem mesmo podem exigir delas documentação que não possam ter, devendo encaminhá-las ao setor adequado para apurar suas necessidades de proteção, inclusive com a criação de uma base de dados que apure o ingresso delas no respectivo território.

Analisa também a questão da criança desacompanhada ou separada da sua família, levando em consideração sua situação de vulnerabilidade, uma vez que o Estado, nesse caso, deverá atuar com maior cautela e prevenção, caso contrário ela poderá tornar-se vítima de tráfico infantil, exploração sexual ou diversas outras formas de abuso ou ações criminosas.

Quanto às crianças vítimas, ou potenciais vítimas, de tráfico, que se encontram em uma situação de extrema vulnerabilidade, os Estados têm o dever de protegê-las contra um novo risco de vitimização ${ }^{16}$ e prestar-Ihes assistência jurídica e médica, ${ }^{17}$ tentando, na medida do possível, proteger a privacidade e identidade da vítima. ${ }^{18}$ Além disso, os Estados, na medida do possível, devem considerar a possibilidade de cumprir os propósitos anteriores através do fornecimento de: a) alojamento adequado; b) assessoramento e informação, em particular com respeito a seus direitos, em um idioma que as vítimas de tráfico de pessoas possam compreender; c) assistência médica, psicológica e material e d) oportunidades de educação e/ou capacitação. ${ }^{19}$ Adicionalmente, devido à especial si-

\footnotetext{
15 Texto extraído do Parecer Consultivo OC-21/14 de 19 de agosto de 2014 sobre direitos e garantias de crianças no contexto da migração e/ou em necessidade de proteção internacional, p. 14.

${ }^{16}$ Ver o artigo 9.1.b do Protocolo Adicional à Convenção das Nações Unidas contra o Crime Organizado Transnacional Relativo à Prevenção, Repressão e Punição do Tráfico de Pessoas, em Especial Mulheres e Crianças.

17 Ver o artigo 6 do Protocolo Adicional à Convenção das Nações Unidas contra o Crime Organizado Transnacional Relativo à Prevenção, Repressão e Punição do Tráfico de Pessoas, em Especial Mulheres e Crianças.

${ }^{18}$ Ver o artigo 6.1 do Protocolo Adicional à Convenção das Nações Unidas contra o Crime Organizado Transnacional Relativo à Prevenção, Repressão e Punição do Tráfico de Pessoas, em Especial Mulheres e Crianças.

${ }^{19}$ Ver o artigo 6.3 do Protocolo Adicional à Convenção das Nações Unidas contra o Crime Organizado Transnacional Relativo à Prevenção, Repressão e Punição do Tráfico de Pessoas, em Especial Mulheres e Crianças.
} 


\section{Humanos e}

Democracia

tuação de vulnerabilidade das vítimas deste delito, os Estados devem, quando proceder, facilitar a obtenção de uma permissão para permanecer em seu território, sobretudo nos casos nos quais seu interesse superior assim o aconselhar ou para continuar com a investigação penal do perpetrador do delito. ${ }^{20}$

Dessa forma, os Estados devem atuar utilizando-se de medidas de investigação, proteção para as vítimas e campanhas de informação e difusão. Além disso, tem-se adotado políticas de controle de fronteiras, por meio da capacitação de funcionários, com o objetivo de prevenir o tráfico de seres humanos.

\subsection{Das garantias do devido processo no âmbito migratório}

A Corte Interamericana analisou também as garantias do devido processo legal nas questões migratórias envolvendo crianças, uma vez que deve ser garantido o direito e condições de se defender adequadamente diante de qualquer ato do Estado ou qualquer autoridade pública, administrativa, legislativa ou judicial, prevalecendo noção de justiça:

"Corte já indicou que o direito ao devido processo se refere ao conjunto de requisitos que devem ser observados nas instâncias processuais para que as pessoas estejam em condições de defender adequadamente seus direitos diante de qualquer ato do Estado, adotado por qualquer autoridade pública, seja administrativa, legislativa ou judicial, que possa afetá-los. ${ }^{21} \mathrm{O}$ devido processo, por sua vez, encontra-se intimamente ligado à noção de justiça, ${ }^{22}$ que se reflete em: (i) um acesso à justiça não apenas formal, mas que reconheça e resolva os fatores de desigualdade real dos processados, (ii) o desenvolvimento de um julgamento justo e (iii) a resolução das controvérsias de forma tal que a decisão adotada se aproxime do maior nível de correção do direito, isto é, que se assegure, na maior medida possível, sua solução justa". ${ }^{23}$

As garantias do devido processo legal são aplicáveis a qualquer pessoa independentemente de sua idade ou nacionalidade. Já é um direito garantido no status migratório, uma vez que o Estado deve oferecer a todo estrangeiro, ainda que em situação irregular, a possibilidade de se fazer valer tais atributos:

Outrossim, as garantias do devido processo são aplicadas a qualquer pessoa independentemente de sua idade e condição de estadia em um país. Nessa perspectiva, a Corte esclareceu que o devido processo legal é um direito que deve ser garantido a toda pessoa, independentemente de seu status migratório. ${ }^{24}$ Isso significa que o Estado deve garantir

\footnotetext{
${ }^{20}$ Ver o artigo 7.1 do Protocolo Adicional à Convenção das Nações Unidas contra o Crime Organizado Transnacional Relativo à Prevenção, Repressão e Punição do Tráfico de Pessoas, em Especial Mulheres e Crianças. Ver, também, Escritório do Alto Comissariado para os Direitos Humanos (OACNUDH), Princípios e Diretrizes Recomendados sobre Direitos Humanos e Tráfico Humano, UN Doc. E/2002/68/Add.1, publicados em 20 de maio de 2002, diretriz 8.

${ }^{21}$ Cf. Garantias Judiciais em Estados de Emergência (arts. 27.2, 25 e 8 Convenção Americana sobre Direitos Humanos), supra, par. 27; Caso do Tribunal Constitucional Vs. Peru. Mérito, Reparações e Custas. Sentença de 31 de janeiro de 2001. Série C № 71, par. 69, e Caso Família Pacheco Tineo Vs. Bolívia, par. 130.

${ }^{22}$ Cf. O Direito à Informação sobre a Assistência Consular no Marco das Garantias do Devido Processo Legal, par. 117

23 Parecer Consultivo OC-21/14 de 19 de agosto de 2014 cit., p. 42.

${ }^{24}$ Cf. Condição Jurídica e Direitos dos Migrantes Indocumentados, pars. 121 e 122, e Caso Vélez Loor Vs. Panamá, par. 143.
} 
que toda pessoa estrangeira, mesmo quando for um migrante em situação irregular, tenha a possibilidade de fazer valer seus direitos e defender seus interesses de forma efetiva e em condições de igualdade processual com outros jurisdicionados. ${ }^{25}$

Ressalta-se que aludidas garantias devem ser respeitadas independentemente das pessoas às quais se refiram, observando-se que, ao se tratar de criança, o Estado deverá conferir a elas uma atenção especial, tendo em vista que o reconhecimento do processo migratório em relação a pessoas adultas não se faz nas mesmas condições de igualdade.

Assim, a própria Corte Interamericana confere às crianças várias garantias no processo migratório, considerando critérios de maiores relevâncias:

Tendo as anteriores considerações como base, a Corte se referirá a seguir às garantias que, conforme o Direito Internacional dos Direitos Humanos, devem reger todo processo migratório que envolva crianças, fazendo menção especial, quando corresponda, àquelas que exigem mais relevância neste tipo de processo. Em consequência, a Corte se referirá aos seguintes aspectos: (i) o direito de ser notificado da existência de um procedimento e da decisão que se adote no âmbito do processo migratório; (ii) o direito a que os processos migratórios sejam conduzidos por um funcionário ou juiz especializado; (iii) o direito da criança a ser ouvida e a participar nas diferentes etapas processuais; (iv) o direito a ser assistido gratuitamente por um tradutor e/ou intérprete; ( $v$ ) o acesso efetivo à comunicação e assistência consular; (vi) o direito a ser assistido por um representante legal e a comunicar-se livremente com este representante; (vii) o dever de designar um tutor no caso de criança desacompanhada ou separada; (viii) o direito a que a decisão adotada avalie o interesse superior da criança e seja devidamente fundamentada; (ix) o direito a recorrer da decisão perante um juiz ou tribunal superior com efeitos suspensivos; e (x) o prazo razoável de duração do processo. ${ }^{26}$

Com isso, exemplificando, o Tribunal reconhece que a falta de notificação ao migrante sobre a existência de um processo acarreta violação ao direito de defesa, que também é estendido às crianças migrantes. Logicamente que, nesse caso, há pessoal especializado para se comunicar com as crianças e tratar do assunto tanto administrativa quanto judicialmente.

Além disso, todo processo migratório deve ser conduzido por um funcionário ou juiz especializado no assunto, garantida a sua imparcialidade e respeito à legislação pertinente.

Importante ressaltar também que, no caso de migrantes menores de idade, as decisões em matéria migratória não poderão ser delegadas a funcionários não especializados, pois os Estados devem garantir que tais decisões sejam feitas por pessoas capacitadas, de forma a identificar as necessidades especiais e de proteção às crianças migrantes.

A criança também precisa ser ouvida nas diversas etapas do processo, pois com isso busca-se o seu melhor interesse. O Estado, no caso das crianças migrantes que não entendam o idioma, deve garantir que elas sejam assistidas por um tradutor e/ou intérprete, sempre com o objetivo de que seus interesses superiores sejam considerados.

\footnotetext{
${ }^{25}$ Cf. Caso Vélez Loor Vs. Panamá, par. 143.

${ }^{26}$ Parecer Consultivo OC-21/14 de 19 de agosto de 2014 cit., p. 44.
} 


\section{Humanos e \\ Democracia}

A Corte menciona ainda que todo funcionário consular tem o dever de zelar primordialmente pelos interesses das crianças, tendo em vista que as decisões administrativas ou judiciais que sejam adotadas no país receptor devem ser avaliadas de acordo com seu interesse superior, na medida em que sua situação de vulnerabilidade, em razão de se encontrarem fora de seu país de origem, desacompanhadas ou separadas de sua família, merece especial atenção por parte das nações.

O Tribunal destaca também que os Estados têm o dever de garantir a toda criança no contexto migratório representação jurídica especializada por meio de serviços estatais gratuitos, respeitando-se o efetivo acesso à Justiça.

No caso de crianças desacompanhadas ou separadas de suas famílias, o Estado tem a obrigação de designar um tutor até que elas atinjam a maioridade, o que ocorre aos 18 (dezoito) anos de idade, podendo, logo após a emancipação, abandonar o território ou a jurisdição daquela nação, devendo, referido tutor, no exercício de sua tutela, conhecer evidentemente os interesses do menor, atendendo-se sempre às necessidades sociais, educativas, jurídicas e psicológicas daquele(a) migrante.

Para as decisões emanadas no âmbito migratório, a Corte menciona que todas elas deverão ser fundamentadas de acordo com a administração da Justiça, garantindo-se sempre o direito das pessoas de não serem julgadas de forma arbitrária numa sociedade democrática.

Em se tratando de decisão, caberá a toda pessoa no contexto migratório o direito de recorrer, com efeito suspensivo, seja no âmbito administrativo ou judicial, de deliberação pela deportação ou expulsão de um país. No caso da criança, esse recurso merece destaque, pois será ele utilizado caso o interesse superior do menor não seja atendido, ou seja, quando de fato não foi a criança devidamente ouvida ou suas opiniões não terem sido consideradas, lembrando que todo o trâmite processual deverá respeitar a duração razoável do processo, sem prejuízo ao direito da criança no que diz respeito à celeridade processual.

\subsection{Do princípio da não privação de liberdade de crianças e do princípio de não devolução (Non-Refoulement)}

Outro ponto importante a ser destacado refere-se ao Princípio da Não Privação de Liberdade de Crianças por sua situação migratória irregular.

Mais especificamente, o Alto Comissariado das Nações Unidas para os Refugiados entendeu, em relação às pessoas em busca de proteção internacional, que a detenção equivale à "privação da liberdade ou confinamento em um local fechado, do qual não se permite que o solicitante de refúgio saia pela própria vontade, incluindo, mas não limitado a presídios ou centros de detenção, instalações de recepção ou retenção" ${ }^{27}$ Além disso, entende que "[a]s distinções entre a privação da liberdade e restrições menores à circulação são de maior ou menor grau de intensidade e não de natureza ou substância". ${ }^{28}$ Por conseguinte, "[q]ualquer que seja o nome dado ao local específico da detenção, as questões mais importantes dizem respeito a se o solicitante de refúgio está sendo privado de sua

\footnotetext{
${ }^{27}$ Alto Comissariado das Nações Unidas para os Refugiados (ACNUR), Diretrizes sobre os critérios aplicáveis e os padrões relativos à detenção de solicitantes de refúgio, e soluções alternativas à detenção, publicadas em 2012, introdução, par. 50.

${ }^{28}$ Alto Comissariado das Nações Unidas para os Refugiados (ACNUR), Diretrizes sobre os critérios aplicáveis e os padrões relativos à detenção de solicitantes de refúgio, e soluções alternativas à detenção, publicadas em 2012, introdução, par. 6 .
} 
liberdade de fato e se esta privação é considerada legal de acordo com o Direito Internacional" ${ }^{29}$ Outorga-se assim, portanto, uma precisão adicional ao conceito de privação de liberdade em hipóteses em que se restringe a liberdade de ir e vir, mas que esta restrição gera, na situação concreta, uma afetação de tal envergadura nos direitos da pessoa, como no direito de solicitar e receber asilo, que essa restrição resulta comparável a uma medida privativa de liberdade em razão do "tipo, duração, efeitos e forma de implementação". ${ }^{30}$

A Corte entende que o princípio de ultima ratio de detenção só deve ser aplicado em último caso como caráter pedagógico do processo penal.

Com efeito, constitui um princípio do Direito Internacional dos Direitos Humanos, ${ }^{31}$ cristalizado na Convenção Sobre os Direitos da Criança ${ }^{32}$ e desenvolvido pela jurisprudência desta Corte no marco do direito à liberdade pessoal em casos relativos a jovens em conflito com a lei penal, ${ }^{33}$ que a privação de liberdade, seja em sua faceta cautelar ou como sanção penal, constitui uma medida de último recurso que deve ser aplicada, quando proceda, pelo menor tempo possível, ${ }^{34}$ dado o objetivo fundamentalmente pedagógico do processo penal relativo a pessoas menores de idade. ${ }^{35} E$ assim que a privação de liberdade no contexto da justiça penal juvenil deve respeitar os princípios de legalidade, excepcionalidade e máxima brevidade. ${ }^{36}$ Além disso, a excepcionalidade da prisão preventiva opera com maior rigorosidade, já que a regra deve ser a liberdade e, caso se verifique a necessidade de cautela, deve primar a aplicação de medidas substitutivas. ${ }^{37}$

De acordo com o Direito Internacional dos Direitos Humanos, a Corte considera que a privação de liberdade das crianças desacompanhadas ou separadas de sua família é totalmente descabida, tendo em vista que o Estado, conforme o Comitê dos Direitos da Criança, está obrigado a garantir uma proteção especial aos menores e buscar atingir seu melhor interesse superior:

\footnotetext{
${ }^{29}$ Alto Comissariado das Nações Unidas para os Refugiados (ACNUR), Diretrizes sobre os critérios aplicáveis e os padrões relativos à detenção de solicitantes de refúgio, e soluções alternativas à detenção, publicadas em 2012, introdução, par. 70, citando TEDH, Caso Guzzardi Vs. Itália, № 7367/76. Sentença de 6 de novembro de 1980, par. 93.

${ }^{30}$ TEDH, Caso Amuur Vs. França, N 19776/92. Sentença de 25 de junho de 1996, par. 42 (tradução da Secretaria da Corte).

${ }^{31}$ Ver a regra 13.1 das Regras mínimas padrão das Nações Unidas para a administração da justiça da criança e do adolescente (Regras de Beijing), UN Doc. A/RES/40/33, adotadas em 29 de novembro de 1985; a regra 6.1 das Regras mínimas padrão das Nações Unidas para a elaboração de medidas não privativas de liberdade (Regras de Tóquio), UN. Doc. A/RES/45/110, adotadas em 14 de dezembro de 1990; a regra 17 das Regras das Nações Unidas para a proteção dos menores privados de liberdade (Regras de Havana), UN Doc. A/RES/45/113, adotadas em 14 de dezembro de 1990, e o princípio III dos Princípios e Boas Práticas sobre a Proteção das Pessoas Privadas da Liberdade nas Américas da Comissão Interamericana de Direitos Humanos, adotados durante o 131ㅇ Período Ordinário de Sessões, celebrado de 3 a 14 de março de 2008.

$32 \mathrm{O}$ artigo 37.b) da Convenção sobre os Direitos da Criança dispõe que os Estados-Partes zelarão para que: nenhuma criança seja privada de sua liberdade de forma ilegal ou arbitrária. A detenção, a reclusão ou a prisão de uma criança será efetuada em conformidade com a lei e apenas como último recurso e durante o mais breve período de tempo que for apropriado.

${ }^{33}$ Cf. Caso "Instituto de Reeducação do Menor" Vs. Paraguai, supra, pars. 230 e 231, e Caso Mendoza e outros Vs. Argentina, par. 162.

${ }^{34}$ Cf. Comitê dos Direitos da Criança, Observação Geral № 10: Os Direitos da Criança no âmbito da justiça de menores, UN Doc. CRC/C/GC/10, 25 de abril de 2007, pars. 70, 79 e 80. Ver, também, Comitê dos Direitos da Criança, Observação Geral № 6: Tratamento dos menores desacompanhados e separados de sua família fora de seu país de origem, par. 61.

${ }^{35}$ Cf. Comitê dos Direitos da Criança, Observação Geral № 10: Os Direitos da Criança no âmbito da justiça de menores, par. 51.

${ }^{36}$ Ver artigo 37.b) e d) da Convenção sobre os Direitos da Criança.

${ }^{37}$ Parecer Consultivo OC-21/14 de 19 de agosto de 2014 cit., p. 54-55.
} 


\section{Humanos e \\ Democracia}

Em aplicação do artigo 37 da Convenção e do princípio do interesse superior do menor, não se deve privar de liberdade, como regra geral, os menores desacompanhados ou separados de sua família. A privação de liberdade não poderá ser justificada apenas porque o menor esteja sozinho ou separado de sua família, nem por sua condição de imigrante ou residente. [...] Por conseguinte, deve ser feito todo o possível, inclusive acelerar os processos pertinentes, com o objetivo de que os menores desacompanhados ou separados de sua família sejam postos em liberdade e colocados em outras instituições de alojamento. $^{38}$

No caso das crianças migrantes, a Corte ainda ressalta que:

Em suma, a Corte entende que as crianças migrantes e, em particular aqueles em situação migratória irregular que se encontram em uma situação de maior vulnerabilidade, requerem do Estado receptor uma atuação especificamente orientada à proteção prioritária de seus direitos, que deve ser definida segundo as circunstâncias particulares de cada caso concreto, isto é, se se encontram com sua família, separados ou desacompanhados, e atendendo o seu interesse superior. Para tanto os Estados, em cumprimento de suas obrigações internacionais na matéria, devem elaborar e incorporar em seu ordenamento interno um conjunto de medidas não privativas de liberdade a serem ordenadas e aplicadas enquanto se desenvolvem os processos migratórios visando, de forma prioritária, à proteção integral dos direitos da criança, de acordo com as características descritas, com estrito respeito de seus direitos humanos e ao princípio de legalidade. ${ }^{39}$

Isso se aplica também na questão dos alojamentos para crianças acompanhadas ou separadas de suas famílias, quando o Estado tem o dever de assegurar espaços de alojamento com infraestrutura apropriada, regime adequado que assegure a proteção de seus direitos, bem como assistência médica, jurídica, apoio educativo e atenção integral, especialmente àquelas portadoras de deficiência física ou de doenças como o HIV/Aids, inclusive com pessoal especializado em Psicologia Infantil.

E por fim, em se tratando do Princípio de Não Devolução (Non-Refoulement), tem se entendido que uma das obrigações internacionais associadas a esse princípio é a proibição à tortura, o que faz com que o Estado respeite normas de direitos humanos e não deporte ou extradite uma pessoa sujeita à jurisdição de outro país, com fundado receio de perigo a sua integridade:

Assim, a partir do artigo 5 da Convenção Americana, lido em conjunto com as obrigações erga omnes de respeitar e fazer respeitar as normas de proteção dos direitos humanos, decorre o dever do Estado de não deportar, devolver, expulsar, extraditar ou remover de outro modo uma pessoa que esteja sujeita à sua jurisdição para outro Estado, ou para

\footnotetext{
${ }^{38}$ Comitê dos Direitos da Criança, Observação Geral № 6: Tratamento dos menores desacompanhados e separados de sua família fora de seu país de origem, supra, par. 61. Ver, também, Relatório apresentado pela Relatora Especial, Sra. Gabriela Rodríguez Pizarro, Grupos específicos e indivíduos: Trabalhadores migrantes, de acordo com a resolução 2002/62 da Comissão de Direitos Humanos, UN Doc. E/CN.4/2003/85, 30 de dezembro de 2002, par. 75.a).

${ }^{39}$ Parecer Consultivo OC-21/14 de 19 de agosto de 2014 cit., p. 62.
} 
um terceiro Estado que não seja seguro, quando exista presunção fundada para crer que estaria em perigo de ser submetida à tortura, tratamentos cruéis, desumanos ou degradantes. $^{40}$

\section{CONCLUSÃO}

Por fim, constata-se que os Estados estão condicionados no respeito aos direitos humanos no campo de circulação de pessoas pelo mundo, com dever de especial proteção aos migrantes indocumentados, tendo em vista que uma nação não mais pode agir, no que diz respeito ao contexto migratório, exclusivamente com base na sua pretensão nacional ou política interna.

\section{REFERÊNCIAS}

BATISTA, Vanessa Oliveira. O fluxo migratório mundial e o paradigma contemporâneo da segurança migratória. Revista Versus Acadêmica, Rio de Janeiro: UFRJ, p. 68-78, nov. 2009.

CANÇADO TRINDADE, A. A. Elementos para un Enfoque de Derechos Humanos del Fenómeno de los Flujos Migratorios Forzados, Cidade da Guatemala, OIM/IIDH (Cadernos de Trabalho sobre Migração n 5), 2001, p. 13,18. COHEN, R.; DENG, F. Masses in Flight: The Global Crisis of Internal Displacement. Washington D.C.: Brookings Institution, 1998. p. 74.

FARENA, Maritza Natalia Ferretti Cisneros. Direitos humanos dos migrantes: ordem jurídica internacional e brasileira. 1. ed. Curitiba: Juruá, 2012.

HOBSBAWM, Eric. Globalização, democracia e terrorismo. Tradução de José Veigas. 4. reimp. São Paulo: Companhia das Letras, 2007.

PARECER CONSULTIVO OC-18/03 de 17 de setembro de 2003, solicitado pelos Estados Unidos Mexicanos. A condição jurídica e os direitos dos migrantes indocumentados.

\footnotetext{
${ }^{40}$ De igual forma, o artigo 70 do Pacto Internacional sobre Direitos Civis e Políticos estabelece: "[n]inguém poderá ser submetido à tortura, nem a penas ou tratamento cruéis, desumanos ou degradantes. Será proibido, sobretudo, submeter uma pessoa, sem seu livre consentimento, a experiências médicas ou científicas". Pacto Internacional sobre Direitos Civis e Políticos, adotado em 16 de dezembro 1966, entrada em vigor em 23 de março de 1976. Os seguintes 31 EstadosMembros da OEA são parte deste tratado: Argentina, Bahamas, Barbados, Belize, Bolívia, Brasil, Canadá, Chile, Colômbia, Costa Rica, Dominica, Equador, El Salvador, Estados Unidos da América, Granada, Guatemala, Guyana, Haiti, Honduras, Jamaica, México, Nicarágua, Panamá, Paraguai, Peru, República Dominicana, San Vicente e Granadinas, Suriname, Trinidad e Tobago, Uruguai e Venezuela. O Comitê de Direitos Humanos das Nações Unidas interpretou essa norma no sentido de incluir um dever dos Estados-Partes de "não [...] expor as pessoas ao perigo de serem submetidas a torturas ou a penas ou tratamentos cruéis, desumanos ou degradantes ao regressar a outro país como resultado de extradição, expulsão ou devolução". Comitê de Direitos Humanos, Observação Geral N²0, Substitui a Observação Geral N 7. Proibição da tortura e dos tratamentos ou penas cruéis (Artigo 70), UN Doc. HRI/GEN/1/Rev.7, 10 de março de 1992, par. 9‥ Este dever surge das obrigações gerais do artigo 2 ㅇ do Pacto, que exige que os Estados-Partes respeitem e garantam os direitos do Pacto a todos os indivíduos que se encontrem em seu território e a todas as pessoas sujeitas à sua jurisdição, o que implica "[n]a obrigação de não extraditar, deportar, expulsar ou retirar de outro modo uma pessoa de seu território, quando há razões de peso para acreditar que existe um risco real de provocar um dano irreparável, como o contemplado pelos artigos 60 [direito à vida] e 7으 [proibição de tortura e outros tratamentos cruéis, desumanos ou degradantes] do Pacto, no país para onde se realizará essa saída forçada ou em qualquer país para o qual a pessoa seja expulsa posteriormente". Comitê de Direitos Humanos, Observação Geral N 31, A natureza da obrigação jurídica geral imposta, UN Doc. CCPR/C/21/Rev.1/ Add.13, 26 de maio de 2004, par. 12. Além disso, em várias decisões sobre casos individuais, o Comitê afirmou que não é possível extraditar, deportar, expulsar ou remover de nenhuma maneira uma pessoa do território de um Estado se existem motivos suficientes para acreditar que existe risco de dano irreparável contra seus direitos, e sem antes tomar em consideração as alegações da pessoa sobre o risco existente. Comitê de Direitos Humanos, Joseph Kindler c. Canadá (Comunicação N 470/1991), UN Doc. CCPR/C/48/D/470/1991, parecer adotado em 11 de novembro de 1993, par. 6.2; Charles Chitat Ng c. Canadá (Comunicação N 469/991), UN Doc. CCPR/C/49/D/469/1991, parecer adotado em 7 de janeiro de 1994, par. 6.2; Jonny Rubin Byahuranga c. Dinamarca (Comunicação N 1222/2003), UN Doc. CCPR/C/82/D/1222/2003, parecer adotado em 9 de dezembro 2004, par. 11.3, e Jama Warsame c. Canadá, (Comunicação N 1959/2010), UN Doc. CCPR/C/102/D/1959/2010, parecer adotado em 1 de setembro 2011, par. 8.3.
} 


\section{Humanos e \\ Democracia}

PARECER CONSULTIVO OC-21/14 de 19 de agosto de 2014 sobre direitos e garantias de crianças no contexto da migração e/ou em necessidade de proteção internacional.

REZEK, Francisco. Direito internacional público: curso elementar. 12. ed. rev. e atual. São Paulo: Saraiva, 2010.

RELATÓRIO do Relator Especial sobre os Direitos Humanos dos Migrantes, Jorge Bustamante. Promoção e Proteção de Todos os Direitos Humanos, Civis, Políticos, Econômicos, Sociais e Culturais, incluindo o Direito ao Desenvolvimento, UN Doc. A/HRC/11/7, 14 de maio de 2009, par. 19.

REDIN, Giuliana. Direito de imigrar: direitos humanos e espaço público. Florianópolis: Conceito Editorial, 2013.

SALADINI, Ana Paula Sefrin. Trabalho e imigração: os direitos sociais do trabalhador imigrante sob a perspectiva dos direitos fundamentais. São Paulo: LTR, 2012.

SOARES, Guido Fernando Silva. Raízes históricas das normas internas de proteção aos estrangeiros - os direitos humanos e a proteção dos estrangeiros. Revista de Informação Legislativa, Brasília: Senado Federal, Subsecretaria de Edições Técnicas, a. 41, n. 162, abr./jun. 2004. (Edição especial comemorativa dos 40 anos).

VEDOVATO, Luís Renato. Direito de ingresso do estrangeiro: a circulação das pessoas pelo mundo no cenário globalizado. São Paulo: Atlas, 2013. Livro digital.

ZOLBERG, Aristide. "Matters of State: theorizing immigration policy". In: HIRSCHMAN, Charles; KASINITZ, Philip; DEWIND, Josh. The handbook of international migration, the American Experience. Nova York: Russel Sage Foundation, 1999. 